

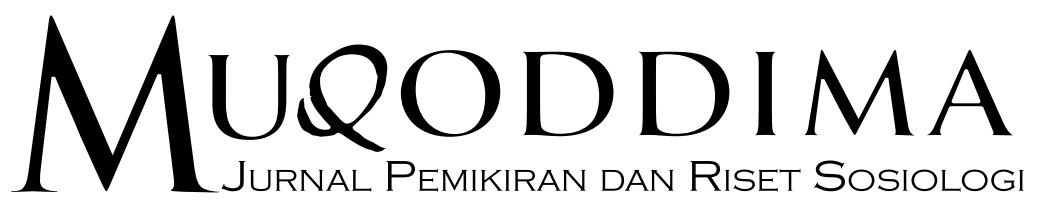




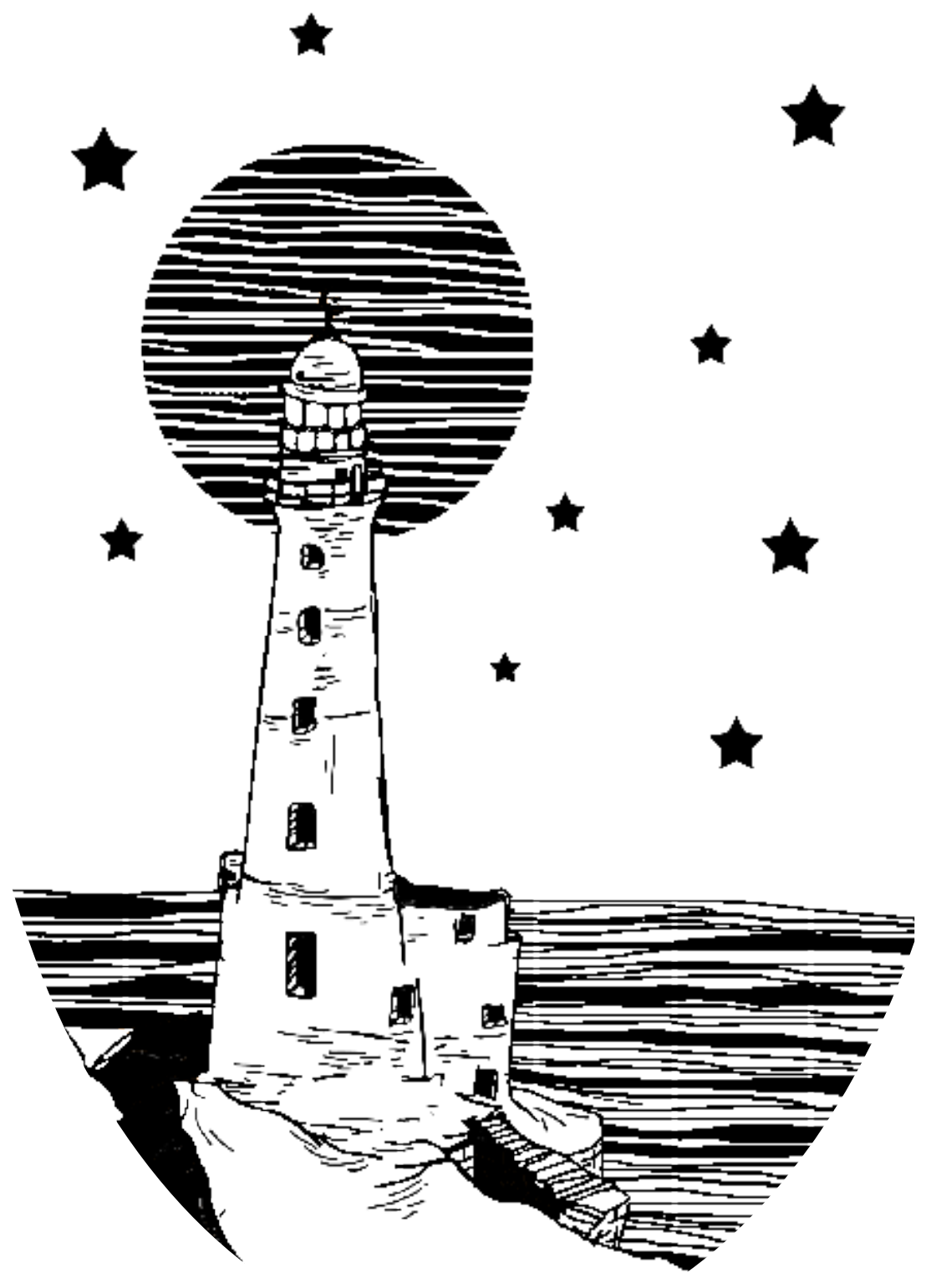




\section{Mugoddima \\ JuRnal PEMikiran dan Riset Sosiologi}

Vol. 1 No. 2 DeSEMBER 2020

ISSN 2745-7168 (DARING)

\section{Editor in Chief}

Eneng Darol Afiah, Universitas Nahdlatul Ulama Indonesia Jakarta

\section{Managing Editor}

Naeni Amanulloh, Universitas Nahdlatul Ulama Indonesia Jakarta

\section{Editor}

Amsar A. Dulmanan, Universitas Nahdlatul Ulama Indonesia Jakarta

Pangeran P.P.A. Nasution, Universitas Malikussaleh

Muhammad Nurul Huda, Universitas Nahdlatul Ulama Indonesia Jakarta

Muhammad Mustafid, Universitas Nahdlatul Ulama Yogyakarta

Mujtaba Hamdi, Universitas Nahdlatul Ulama Indonesia Jakarta

Fikri Tamau, Universitas Pembangunan Nasional Veteran Jakarta

Hanifa Maulidia, Sekolah Tinggi Imigrasi

Dewi Anggraeni, Universitas Nahdlatul Ulama Indonesia Jakarta

Muhammad Nurun Najib, Universitas Nahdlatul Ulama Indonesia Jakarta

R.M. Joko P. Mulyadi, Universitas Nahdlatul Ulama Indonesia Jakarta

Moh. Faiz Maulana, Universitas Nahdlatul Ulama Indonesia Jakarta

\section{Reviewer}

Achmad Munjid, Universitas Gajah Mada, Yogyakarta, Indonesia

Ahmad Suaedy, Universitas Nahdlatul Ulama Indonesia, Jakarta, Indonesia

Syamsul Hadi, Universitas Nahdlatul Ulama Indonesia, Jakarta, Indonesia

Moh. Yasir Alimi, Universitas Negeri Semarang, Semarang, Indonesia

Nadiatus Salama, Universitas Islam Negeri Walisongo, Semarang, Indonesia

Anton Novenanto, Universitas Brawijaya, Malang, Indonesia

Akhmad Ramdhon, Universitas Sebelas Maret, Surakarta, Indonesia

Imam Ardhianto, Universitas Indonesia, Jakarta, Indonesia

Achmad Fawaid, Universitas Nurul Jadid, Probolinggo, Indonesia

Fariz Alnizar, Universitas Nahdlatul Ulama Indonesia, Jakarta, Indonesia

Pajar Hatma Indra Jaya, Universitas Islam Negeri Kalijaga, Yogyakarta, Indonesia

\section{Ilustrasi Cover}

'Menara Petunjuk', Shilfina Putri Widatama 
MUQODDIMA Jurnal Pemikiran dan Riset Sosiologi diterbitkan oleh Laboratorium Sosiologi, Departemen Sosiologi, Fakultas Sosial dan Humaniora, Universitas Nahdlatul Ulama Indonesia (UNUSIA) Jakarta. Jurnal ini terbit dua kali setahun, yaitu pada Juni dan Desember.

MUQODDIMA Jurnal Pemikiran dan Riset Sosiologi menyajikan karya-karya ilmiah di bidang sosiologi dan sosial humaniora. MUQODDIMA Jurnal Pemikiran dan Riset Sosiologi mengarahkan diri pada kajian sosial-keagamaan, budaya, politik-ekonomi, serta isuisu kemanusiaan dan lingkungan hidup baik yang dihasilkan dari penelitian lapangan maupun tinjauan kritis atas teori sosial. MUQODDIMA Jurnal Pemikiran dan Riset Sosiologi mengundang para akademisi dan peneliti di bidang sosial humaniora, khususnya sosiologi, serta para praktisi/aktivis sosial untuk mengirimkan karyanya.

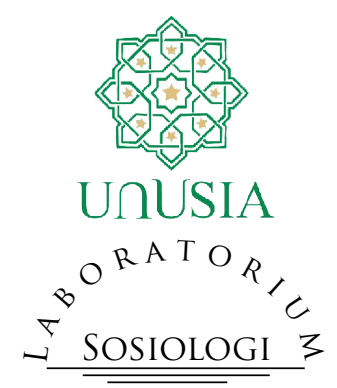

\author{
Alamat Editorial: \\ Kampus UNUSIA Jakarta \\ Jl. Taman Amir Hamzah No. 5 \\ Jakarta Pusat 10430 \\ Telp/Fax: (021) 3156864 / 3906501 \\ E-mail: muqaddima.jms@unusia.ac.id \\ Website: http://journal.unusia.ac.id/index.php/Muqoddima
}




\section{MUgoddima \\ Jurnal PEMIKIRAN dan Riset Sosiologi}

Vol. 1 No. 2 Desember 2020

\section{DAFTAR IsI}

\section{Pengantar Editorial}

i-x $\mid$ ENENG Darol Afiah

Membaca Ulang ‘Guncangan Besar' Francis Fukuyama

\section{Artikel}

113-132 Rachmad K. Dwi Susilo

Sosiologi Sebagai the Queen of Social Sciences: Sebuah Refleksi

133-144 Taufik Hidayadi \& Henny Saptatia Drajati Nugrahani Stereotip Warga Tionghoa dalam Geopolitik Hubungan Indonesia dengan Tiongkok

145-164 FARIZ AlNiZAR

Antara Iman dan Kenikmatan:

Konstruksi Gagasan Pascamodernisme Ariel Heryanto

165-180 NANA KRISTIAWAN

Dinamika Pengelolaan Sumber Daya Air di Situ Kemuning, Cimanggis Kabupaten Bogor

181-196 INDHAR WAHYU Wira HaRjo

Konsolidasi Demokrasi Melalui Liga Santri Nusantara

197-210 MoH. Faiz Maulana

Dangdut Koplo: Tubuh, Seksualitas, dan Arena Kekuasaan Perempuan

211-230 Elmy Bonafita ZaHro

Smoking Outcome Expectancy: Pengetahuan, Perilaku, dan Konsekuensi Merokok

\section{Telaah Buku}




\title{
Sosiologi Sebagai the Queen of Social Sciences: Sebuah Refleksi
}

\author{
Rachmad K. Dwi Susilo \\ Program Studi Sosiologi FISIP Universitas Muhammadiyah Malang \\ E-mail: rachmad@umm.ac.id
}

\begin{abstract}
Abstrak
Sosiolog adalah pekerjaan mulia, karena sosiolog adalah orang-orang yang mengetahui, memahami, dan menguasai relung masyarakat baik yang terlihat (manifest) maupun yang tidak terlihat (laten), baik sisi masyarakat yang terletak di permukaan maupun di bagian terdalam. Namun bila kita temukan di lapangan, sosiologi tampak masih belum berdaya. Tugas kenabian dan kekhalifahan yang melekat pada sosiolog sulit dibuktikan. Persentase keterlibatan ilmiah sebagian besar ditempati oleh ilmuwan sosial politik terapan. Padahal umur sosiologi cukup panjang: Ibnu Khaldun mengembangkan sosiologi pada abad ke-14; August Comte memberi nama Sosiologi pada abad ke-18; dan di Indonesia, jika dihitung dari Selo Soemardjan yang menyelesaikan studinya dari Amerika pada tahun 1959, umur sosiologi berusia 61 tahun. Sosiologi juga memiliki jargon yang menjadi klaimnya: ratu ilmu sosial. Namun pertanyaannya, apakah sosiologi benarbenar ratu? Walaupun sosiolog Indonesia sudah memiliki asosiasi baik ISI (Ikatan Sosiologi Indonesia) maupun APSSI (Asosiasi Program Studi Sosiologi Indonesia) yang sudah cukup aktif bekerja, kita kesulitan menemukan model sosiolog ideal dalam dunia profesional. Penulis menyadari bahwa universitas belum berhasil menghasilkan sosiolog yang benar-benar dapat bekerja tanpa atribut akademik. Melalui tulisan ini, penulis bermaksud untuk memahami dan menjelaskan dilema yang dihadapi oleh sosiologi dan sosiolog Indonesia serta usulan langkah untuk mengatasinya. Penulis memulai dari permasalahan mendasar yang kemudian dikaitkan dengan prinsip dasar dalam sosiologi.
\end{abstract}

Kata Kunci: asosiasi, rumah sosiologi, persoalan mendasar, prinsip dasar, sosiologi, sosiolog 


\begin{abstract}
Sociologists are noble expertise, because sociologists are the ones who know, understand and master the niches of society both visible and invisible. Both the side of society which is located on the surface and in the deepest part are understood by sociologist. However, when we find in the field, sociology is still powerless. The task of prophecy and the caliphate that are inherent in sociologists is difficult to prove. The percentage of scientific involvement is mostly occupied by applied socio-political scientists. In fact, the age of this knowledge is quite long, Ibn Khaldun developed sociology in the 14th century, and August Comte gave the name Sociology in the 18th century. In Indonesian context, if it is calculated from Selo Soemardjan completing his studies from America in 1959, the age of sociology is 61 years old. Sociology has its jargon as the queen of the social sciences but, however, the question, is sociology really the queen? Even though Indonesian sociologist already have associations of both ISI (Indonesian Sociology Association) and APSSI (Indonesian Sociology Departement Association) that have been working quite actively, we have difficulty finding good models of sociologists in the professional field. The author realizes that the university has not succeeded in producing sociologists who can truly work without academic attributes; therefore, the purpose of this article is to understand and explain the dilemmas faced by sociology and Indonesian sociologists; then, unravel these convoluted problems and then propose steps to solve the problems. The author starts from the fundamental problems which are then linked to basic principles in sociology. Then, building a sociology house and sociological challenges. Finally, the writer proposes as a solution.
\end{abstract}

Keywords: sociology, sociologist, association, sociology house, fundamental problems, basic principles, sociology, sociologist

\title{
Pendahuluan
}

Sosiolog itu pekerjaan mulia, karena sosiologlah pihak yang mengetahui dan memahami relung-relung masyarakat baik yang terlihat maupun yang tidak terlihat. Baik yang terletak di permukaan maupun pada bagian mendalam. Selain itu, salah satu peran sosiolog yakni mengkomunikasikan ilmunya yang sekaligus mencerdaskan masyarakat.

Bagi sosiolog, mempelajari realitas tidak akan pernah berhenti karena banyak hal misterius dari masyarakat itu. Masyarakat merupakan organisme dinamis yang selalu bergerak. Bagi pembelajar sosiologi, satu bagian telah selesai dipelajari, muncul sesuatu yang baru pada bagian lain. Bisa dikatakan bahwa sosiolog mempelajari sesuatu yang misterius dan obyek ini tidak pernah berakhir.

Hal-hal misterius memicu keingintahuan, dan berawal dari keingintahuan tersebut, sosiolog dituntut menjawab keingintahuan dan pertanyaan yang datang bertubi-tubi. Ditemukannya satu jawaban sementara akan disusul perubahanperubahan realitas di luar rencana kita. Sosiolog dirundung kegelisahan untuk menjawab pertanyaan-pertanyaan yang datang belakangan. Sosiolog adalah 
manusia yang selalu gelisah.

Apa yang bisa dilakukan oleh para sosiolog tersebut mengingatkan kita pada Rasulullah Muhammad SAW. Ketika ia beruzlah di gua Hira, rasulullah selalu gelisah, merenung dan memikirkan kebobrokan masyarakat Makkah. Rasulullah terus menerus mencari jawab kemudian praksis melakukan tindakan (action) kerja-kerja lapang. Ia tidak sekedar berteori, apalagi sekedar mengkritik, tetapi merekonstruksi masyarakat agar terjadi perubahan seperti diidealkan (Ali 2020).

Identik dengan kerja kenabian, pekerjaan sosiologi adalah memahami realitas, memprediksikan dan bahkan melakukan perubahan-perubahan siginifikan di masyarakat. Mengingat pekerjaan sosiolog adalah pengejar kebenaran dan kebenaran ada dimana-mana, maka status sosiolog ini flaksibel. Oleh karena itu tentunya bisa digabung dengan status dan peran lain, misalnya sosiolog merangkap sebagai seorang guru, pegawai pemerintah, atau pengusaha.

Belajar sosiologijuga tidak lepas dari perilaku beragama, peran-peran seorang sosiolog bisa dimainkan. Sosiolog mengatakan melakukan kerja-kerja pencerahan sementara itu seorang muslim melakukan kerja-kerja kekhalifahan dengan peran sebagai wakil Tuhan di muka bumi, maka fungsi khalifah yakni memakmurkan bumi tersebut (Shihab 2020:40).

Semoga pernyataan di atas bukan sekedar 'cerita-cerita penghibur' untuk sosiolog pemula yang sedang melakukan pencarian di tengah kegalauan menjadi mahasiswa sosiologi. Janganlah cerita di atas sekedar penghibur yang akhirnya menjelma sebagai ilusi yang diproduksi dosen sosiologi di kelas-kelas.

Kenyataan di luar sana, sosiologi tidak berdaya. Kalimat yang menginspirasi sebagai tugas kenabian dan kekhalifahan ternyata sulit dibuktikan di lapang. Prosentase keterlibatan keilmuwan banyak dihuni ilmuwan-ilmuwan sosial politik terapan. Padahal, usia ilmu ini sudah cukup lama. Kalau menggunakan peran Ibnu Khaldun pada abad ke-14, August Comte memberi nama Sosiologi abad ke 18 atau jika dihitung dari Selo Soemardjan menyelesaikan kuliah dari Amerika tahun 1959, Sosiologi di Indonesia sudah berusia 61 tahun. Demikian pula mengingat jargon ilmu ini sosiologi sebagai ratunya ilmu-ilmu sosial, pertanyaannya, benarkah ia benar-benar ratu?

Sekalipun sudah memiliki asosiasi baik ISI (Ikatan Sosiologi Indonesia) maupun APSSI (Asosiasi Program Studi Sosiologi Indonesia) yang bekerja cukup aktif, tetapi kita kesulitan mencari contoh-contoh lapangan kiprah dari para sosiolog. Wacana-wacana yang diproduksi sosiolog hanya berputar-putar pada "dari, oleh, dan untuk Sosiolog" atau banyak berkutat pada kebutuhan saja, identik kerja wacana tidak matang dan jauh dari berkomunikasi dengan stakeholder.

Memang, ada cerita-cerita yang cukup menghibur dimana para akademisi berlatar belakang sosiologi tetap mendapat tempat. Penulis sangat bangga ketika Sosiolog UI, Imam B. Prasojo tampil di media karena membela Bambang Wijoyanto ketika hendak "dikriminalisasi" oleh Polri pada saat keriuhan terjadi di KPK (Komisi Pemberantasan Korupsi). Hebatnya, dia bisa menggalang dukungan mahasiswa untuk berdemonstrasi ke Kantor KPK. Penulis bisa memahami Imam 
ketika ia gelisah dengan realitas bangsa yang semakin terpuruk. ${ }^{1}$ Bahkan ketika Indonesia diterpa pandemi, sosiolog berkontribusi.

Penulis juga bangga ketika Thamrin Amal Tamagola mengingatkan Presiden Jokowi ketika hendak memilih anggota Wantimpres. Penulis juga bangga dengan Meutia Gani yang menjadi salah satu anggota panitia khusus KPK. Penulis bangga kepada mereka yang sudah melakoni langkah-langkah praksis dan juga memiliki kontribusi riil.

Namun kebanggaan itu tiba-tiba sirna. Benarkah mereka bisa mengakses dikarenakan status mereka Sosiolog? Penulis tidak yakin jika akses ke struktur pemerintahan karena semata-mata prestasi atau kompetensi. Sekalipun bisa diperdebatkan, sudah menjadi rahasia umum kalau kontribusi akademisi tidak lepas dari lobi atau kedekatan dengan stakeholder.

Penulis tidak yakin jika klaim sosiolog yang menguasai segala masalah sosial juga akan mampu menyelesaikan masalah pada saat diterjunkan pada level eksekusi. Pendapat ini setidak-tidaknya diperkuat pengalaman penulis selama 4 (empat) tahun (2013-2017) pada saat menjadi salah satu pendamping gerakan konservasi mata air di Kota Batu, Jawa Timur. Pengalaman ini merupakan refleksi sosiologis yang cukup berharga. Di lapangan, penulis bekerja bersama aktor-aktor komunitas dan praktisi LSM (Lembaga Swadaya Masyarakat) maupun akademisi ilmu hukum.

Para ahli hukum mengritisi praktek kebijakan dan ahli administrasi meneliti pelanggaran administrasi pada kebijakan. Sementara itu, penulis berkonsentrasi pada penguatan kelembagaan dan masyarakat. Pada saat melakukan pekerjaan ini penulis iri dan selalu melakukan refleksi, apa yang bisa disumbangkan Sosiologi untuk keberhasilan gerakan ini? Aktor yang menekuni ilmu terapan seakan memiliki jalan terang atau road map agar aksi menemui keberhasilan. Sempat penulis tertantang menjelaskan teori-teori klasik, modern dan kritis dalam advokasi, tetapi niatan ini diurungkan dengan pertimbangan ia kurang berguna di lapang. Terlebih jawaban yang kita berikan kalau hanya mengandalkan pikiran sesaat tanpa dilengkapi data-data lapang spesifik dan mendalam.

Kegelisahan ini semakin membesar ketika sebagai pengajar penulis menyaksikan mahasiswa dan bahkan lulusan yang masih menemui kebingungan menentukan kompetensi, apakah menekuni analisa teoritis atau menekuni ketrampilan pendampingan lapang? Belum lagi kalau melihat keberpihakan para sosiolog, apakah mereka benar-benar tetap bekerja menggunakan etika keilmuwan atau hanya mengejar kepentingan-kepentingan pragmatis?

Di sini penulis menyadari bahwa kampus belum berhasil melahirkan sosiolog yang benar-benar bisa bekerja tanpa embel-embel akademis. Heryanto menyatakan bahwa ilmu sosial masih terjebak pada kegiatan yang tersebar, tercerai berai, terpotong-terpotong dan sebagaian besar tidak memiliki kesinambungan yang rapi (Heryanto 2006:66). Jangan-jangan benar apa yang dinyatakan oleh

1 Imam Prasojo Minta Kriminalisasi KPK dihentikan, dalam http://news.detik.com/read/2015/02/18/ 183433/2837142/10/imam-prasodjo-minta-kriminalisasi-ke-kpk-dihentikan 
Heru Nugroho dalam Pidato Pengukuhan Guru Bidang Sosiologi di UGM (Universitas Gadjah Mada) 14 Februari 2012. Karena etos yang rendah, akhirnya sosiologi berkembang sangat lambat. Inilah yang dinyatakan fenomena banalitas intelektual yang tengah terjadi di kalangan akademisi. Ilmuwan sosiologi beretos kerja rendah dan rendah pula keberpihakan mereka pada kelompok tertindas yang berimplikasi pada gagalnya mengomunikasikan sosiologi sebagai ratunya ilmu-ilmu sosial (the queen of social sciences).

Terus terang penulis agak frustasi dengan kontribusi sosiologi akhir-akhir ini. Hal ini mengingatkan wawancara Prisma, 1 Januari 1994 dengan Selo Soemardjan bahwa "Ilmu-Ilmu Sosial di Indonesia Mandeg?" bukan karena tidak ada bahan atau materi untuk mengembangkan itu mengingat Indonesia adalah laboratorium ilmu sosial yang berkembang pesat. Bukankah banyak karya ilmu sosial politik yang lahir dari data-data di Indonesia? Persoalannya, popularitas pengkaji yang tidak menanjak.

Kegelisahan-kegelisahan tentang defisitnya peran ilmuwan sosiologi sesungguhnya yang mendorong penulis menulis artikel ini. Tujuan penulisan yaitu menjelaskan dilema yang dihadapi sosiologi dan para sosiolog Indonesia yang kemudian mengurai persoalan yang membelit tersebut dan kemudian mengusulkan langkah-langkah keluar dari persoalan itu. Manfaat tulisan ini yaitu para pembelajar sosiologi bisa menemukan katup penyelamat (safety valve) kegelisahan dan memberi rekomendasi untuk mengatasi persoalan-persoalan para pengkaji sosiologi di dalam merealisasikan tujuan keilmuwan mereka.

\section{Metode dan Struktur Penulisan}

Adapun metode yang penulis gunakan yakni studi literatur dan refleksi pengalaman aksi-aksi praksis baik selama mengembangkan materi pembelajaran, aktif di asosiasi baik Ikatan Sosiologi Indonesia Malang Raya dan sekitarnya maupun Asosiasi Pengelola Program Studi Sosiologi (APPSSI) dan berinteraksi dengan stakeholder lapang, terutama pada saat menginisiasi gerakan advokasi dan konservasi lingkungan di Kota Batu. Aksi-aksi lapang merupakan sarana memutahirkan teori, data-data lapang, memverifikasi data maupun melakukan kerja-kerja pencerah publik. Selain itu, pekerjaan konservasi merupakan upaya untuk mengembangkan pendekatan kualitatif Participatory Action Research (PAR). Kegiatan ini penulis lakukan dari 2013 sampai 2018. Dari kedua pekerjaan mengaitkan teks dengan konteks tersebut penulis rajin mengamati dan menuliskan pada catatan lapang. Bertemu dengan banyak stakeholder sebagai pemakai sosiologi jelas akan memperkaya khazanah lapang penulis

Untuk itu struktur penulisan artikel ini bisa penulis jelaskan sebagai berikut. Tulisan diawali dengan memaparkan persoalan mendasar yang dihadapi sosiologi, menyegarkan prinsip-prinsip dasar dari sosiologi yang bertujuan menyegarkan ingatan kita. Kemudian mengangkat isu berupa mendudukkan teori dengan lapangan. Yang akhirnya, penulis merekomendasikan upaya membangkitkan sosiologi yang penulis nyatakan sebagai membangun "Rumah" Sosiologi. Penulis 
menutup tulisan ini dengan rekomendasi tentang merawat Sosiologi yang sekaligus berupa pengembangan sosiologi ke depan.

Bagian ini dimulai dengan mencari sebab-sebab mendasar defisitnya peran Sosiolog. Untuk itu, dua tema penting perlu penulis diskusikan. Pertama, kajian sosiologi sebagai ilmu pengetahuan (science) dan yang kedua, persoalan ilmuwan sosiologi tersebut. Bagian kedua perlu penulis jelaskan karena terkait dengan yang pertama, bukankah ilmu pengetahuan akan terkomunikasikan sebagai sebuah kenyataan objektif berkat peran dari ilmuwan sosial itu sendiri?

Persoalan pertama yaitu kajian ilmuwan sosiologi yaitu masyarakat. Sisi kelebihan sosiologi yang tidak ditemukan pada ilmu pengetahuan eksakta yaitu kajian mudah ditemukan, artinya masyarakat dan pernak pernik di dalamnya dapat ditemukan di sekitar pengkaji. Namun, kelemahan yang tertinggal yakni obyek ini sangat luas karena masyarakat itu bukan entitas dengan pengertian tunggal. Dimensi ruang dan waktu menyebabkan ia bukan benda tunggal. Sebagai studi ia memiliki banyak konsekuensi negatif dari pada konsekuensi positif. Konsekuensi negatifnya yakni studi tidak spesifik, seperti kita tidak pernah kita sampai tuntas mendefinisikan masyarakat hari ini. Terlebih para sosiolog memberi nama masyarakat dengan berbagai terma seperti: masyarakat konsumsi, masyarakat beresiko, masyarakat digital dan lain-lain.

Kemudian spesialisasi belum tertata, karena para sosiolog bingung menentukan kajian karena dimensi masyarakat beragam. Masuk akal jika rata-rata ilmuwan sosiologi tidak memiliki semacam agenda-agenda atau peta jalan (road map) pembelajaran individual. Jika diberi pertanyaan, anda sosiolog ahli di bidang apa? Rata-rata tidak bisa menjawab, bahkan ada yang menjawab yang tampaknya tidak serius-semuanya bergantung permintaan stakeholder.

Konsekuensi tidak dimilikinya roadmap menjadi akar persoalan itu. Konsep, teori, metodologi dan isu-isu klasik maupun mutakhir tidak dipahami dengan baik. Padahal setiap kajian sosiologi memiliki isu berbeda. Para sosiolog sering kurang memperhatikan epistemologi, ontology, dan aksiologi dari studinya tersebut, padahal ini bagian penting ilmu pengetahuan (science). Sosiolog akan fokus pada level mikro, meso, atau makro? Termasuk jauhnya pertanggungjawaban sosiolog baik secara teoritis maupun praktis. Singkatnya, kita dihadapkan para pengkaji yang miskin visi keilmuwan.

\section{Diskusi}

\section{Prinsip-Prinsip Dasar}

Prinsip-prinsip dasar bersosiologi yakni mengerti dan memahami fakta/ realitas sosial. Sebagai tahapan-tahapan penulis meringkasnya yaitu: 1) tahapan basis pemahaman sosiologi, 2) tahapan kecerdasan sosiologis, dan 3) tahapan ketrampilan sosiologis. Tahapan tersebut diawali dengan penguasaan basis seperti konsep, teori dan metode yang kemudian dilanjutkan dalam studi perspektifperspektif sosiologi.

Dalam pertemuan-pertemuan di kelas, pertemuan antar pengkaji sosiologi 
yang ditekankan adalah konsep-konsep. Pembelajar diajari bagaimana mengurai konsep dan teori dari kelahiran, definisi, bahkan sampai mengkritisi. Sesekali ke lapangan atau menganalisa karya sastra untuk mengobservasi dan mewawancarai informan demi memahamkan konsep tersebut. Konsep jumlahnya ratusan atau bahkan ribuan. Tetapi, ingat konsep/teori tersebut selalu dinamis dan selalu berkembang. Bisa jadi banyak konsep baru bermunculan dan belum ditulis dalam buku-buku baku, akhirnya cukup banyak energi yang dikeluarkan untuk mengkritisi konsep tersebut.

Kemudian tahapan selanjutnya yakni memahami perspektif-perspektif sosiologi. Setidak-tidaknya perspektif fungsionalis, konflik dan interaksionis. Dari pemahaman perspektif kita akan mampu menggabungkan konsep-konsep dalam suatu kesatuan, sehingga pendekatan sosiologi utuh dan sistematis. Setidaktidaknya apa yang menjadi lingkup kajian tidak bertabrakan atau overleaping dengan studi-studi non sosiologis. Jika peneliti bermaksud menjelaskan fenomena/ fakta makro sosiologi, maka perspektif yang dipilih yakni fungsionalis. Konsepkonsep yang digunakan seperti sistem sosial, keteraturan sosial dan fakta sosial.

Sedangkan, perspektif mikro menggunakan konsep-konsep sosiologi, seperti makna, persepsi dan nilai-nilai. Ia tidak akan mencampur konsep-konsep makro dengan konsep mikro. Justru konsep-konsep mikro yang selalu diperdalam yang melahirkan perkembangan konsep-konsep yang lebih mutakhir.

Prinsip-prinsip dasar ini akan melahirkan perbedaan-perbedaan pendekatan dalam ilmu sosial, seperti pendekatan ilmu yang hanya mendeskripsikan realitas saja atau menyusun gagasan-gagasan perubahan sosial. Rajesh Tandon menyatakan bahwa riset akademis dimana memiliki tiga karakter jelas, yakni: 1) pilihan masalah didasarkan atas kepentingan dan disiplin peneliti profesional, 2) pilihan metode yakni desain riset eksperimental, pemanfaatan instrumen andal/ analisa data statistik, dan 3) pilihan hasil sekedar publikasi dalam seminar yang dihadiri oleh para ahli (Tandon dalam Fernandesh, Walter, dan Rajesh Tandon 1993:10).

Setelahlangkah ini, barulah kita memasuki kecerdasan sosiologis. Pemahaman konsep dan teori melahirkan kecerdasan. Sosiologi berupaya membekali diri dengan perangkat-perangkat (tools) tentang pembacaan masyarakat secara tepat. Jika para pembelajar sudah sampai mengerti esensi dari ilmu ini, maka ia mampu mengendalikan sosiologi untuk memandu hidup, seperti menyelamatkan diri sendiri dari berbagai jenis "risiko-risiko" yang tidak mengenakkan (Susilo 2007).

Kecerdasan tidak ada artinya jika tidak dinaikkan menjadi karya nyata, maka kecerdasan naik ke keterampilan-keterampilan sosiologis. Di sini para pengkaji sosiologi mampu mempraktikkan konsep, teori dan atau metodologi untuk menyelesaikan masalah-masalah sosial di lapang. Meminjam bahasa Bruhn dan Rebach (2007), sosiolog mampu melakukan intervensi sosial yang dimulai dari penilaian persoalan sampai menentukan tindak lanjut. Ia tidak hanya membekali pemberdayaan masyarakat, tetapi juga pendampingan dan pelatihan lapang.

Salah satu bentuk karya dari sosiologi adalah perubahan sosial di masyarakat, entah pada level mikro, meso maupun makro. Oleh karena itu, sosiologi harus 
dikembalikan sebagai ilmu yang berkontribusi ke masyarakat atau dalam bahasa Tandon di atas sebagai ilmu partisipatoris. Pertanyaannya, seberapa jauh ia berkontribusi pada pengembangan masyarakat itu. Karya-karya sosiologis sebagai gagasan yang dibukukan atau produk-produk pemberdayaan yang bisa dinikmati masyarakat. Karya ini seringkali tidak terukur karena hal itulah karakter ilmu sosial, maka ia tidak bisa disamakan dengan ilmu-ilmu yang teknis.

\section{Mendudukkan Teori dengan Data Lapangan}

Seperti penulis singgung di muka, sosiologi memiliki lebih dari satu pendekatan mengingat karakter sosiologi adalah ilmu multiperspektif/ multiparadigmatik (Ritzer 2013:101). Artinya, untuk menjelaskan fakta/fenomena sosial, para ilmuwan sosial membuka diri atas paradigma-paradigma yang berbeda dan bahkan mungkin bertentangan.

Misalnya, kemiskinan. Kemiskinan akan dilihat tidak sama antara paradigma fungsionalis dengan paradigma fenomenologi. Fungsionalisme melihat kemiskinan dari bagaimana fungsi atau kontribusi obyektif bagi masyarakat, sedangkan fenomenologi melihat kemiskinan sebagai fenomena erat dengan subyektivitas manusia. Fenomenologi lebih memilih aspek subyektif mikro dari pada obyektif makro. Fenomenologi tidak memperhatikan fungsi, tetapi akan banyak melontarkan pertanyaan mengapa orang menjadi miskin, pengetahuan kemiskinan yang taken for granted dan apa konsepsi individu-individu tentang kemiskinan itu?

Dengan menyandang sebagai ilmu multiparadigmatik bukan berarti hanya konsekuensi positif saja yang diperoleh, multiparadigma juga melahirkan konsekuensi negatif. Sosiologi kaya akan pendekatan dan sangat demokratis. Beragamnya paradigma dan kebebasan perspektif menyebabkan ilmu ini meluas. Klaim satu paradigma sebagai sesuatu yang tepat. Semua paradigma adalah benar, karena memang realitas sosial tidak bisa hanya dilihat pada satu dimensi saja.

Namun jangan berpuas dulu, kondisi ini menyebabkan sosiologi kurang memiliki fokus jelas. Pembelajar pemula sosiologi awal khususnya, sering bingung, manakah teori yang paling benar. Akhirnya, para sosiolog tersebut tidak mengerti manakah yang harus dipilih?

Belum lagi jika dikaitkan dengan kapasitas sosiolog dalam memahami sosiologi, belum tentu ia sanggup memahami semua perspektif. Bukankah ia terbentang dari sosiologi klasik, sosiologi modern, sosiologi posmodern, sosiologi postsrukturalisme sampai poskolonialitas? Masing-masing kategori tadi didukung oleh banyak ahli teori. Bukankah kondisi ini membuat kita frustasi belajar sosiologi? Dalam pelatihan dengan guru-guru SMU bidang sosiologi pernah ada celutukan terkait kesulitan belajar Sosiologi, "Memahami satu perspektif saja belum jelas, kemudian dituntut mempelajari perspektif-perspektif yang lain".

Berangkat dari 'dilemma' yang dihadapi di atas, penulis mencoba mendiskusikan persoalan-persoalan pengembangan ilmu sosiologi ini, sebagai berikut. 


\section{a) Kebenaran adalah final}

Maksud dari kajian ini yaitu para sosiolog harus concern pada kebenaran sebagai produk final. Ia selalu memperlakukan kebenaran itu baik pada waktu menemukan kebenaran maupun menemukan hasil akhir yang menyimpulkan kebenaran sementara itu. Sekalipun kebenaran itu beragam, bahkan di tengah era pragmatis, untuk hidup layak orang bisa hidup tanpa kebenaran. Cukup dengan klaim-klaim tertentu, orang bisa kaya dan terkenal, tetapi, sosiolog tidak boleh terpengaruh. Ia harus menjadikan kebenaran sebagai alat untuk bekerja. Berkualitas dan tidaknya kerja sosiolog sangat ditentukan sejauh mana upaya menghasilkan kebenaran final.

\section{b) Teori atau lapang}

Konsekuensi dari transisi dari ilmu murni ke ilmu terapan membimbing pada sebuah pertanyaan kita akan fokus pada teori atau lapang. Pembelajar sosiologi pasti mengalami pengajaran sosiologi yang fokus teori dan lapang. Kedua-duanya memiliki kajian tersendiri. Kecenderungan di atas disebabkan pengembangan ilmu pengetahuan sebagai puritan-elitis dan kedua yakni kecenderungan pragmatis (Keraf 2001: 153).

Kecenderungan puritan elitis beranggapan bahwa tujuan akhir dari ilmu pengetahuan modern adalah demi ilmu pengetahuan. Penjelasan ilmu pengetahuan ini dipertahankan untuk demi kebenaran murni. Kepuasan ilmuwan yakni menemukan sesuatu dan membongkar teka-teki. Hal terpenting yakni membangun teori-teori besar, bermanfaat atau tidak ilmu pengetahuan tidak menjadi persoalan. Konsekuensinya, ilmu pengetahuan menjadi sangat elitis.

Ilustrasi karakter ini misal, menjelaskan karakter masyarakat terus melakukan studi konsep-konsep yang mendukung itu. Kita ingin menjelaskan masyarakat hari ini, maka teori yang dikembangkan teori tentang masyarakat digital. Berbagai konsep digali dan ditelusuri kerangka teorinya. Akhirnya, hanya pemutiranpemutahiran saja.

Sementara itu kecenderungan pragmatis menyatakan bahwa ilmu pengetahuan tidak berhenti pada upaya mencari kebenaran. Kebenaran dan penjelasan itu penting, tetapi penting pula yakni hasil penelitian berguna bagi masyarakat misalnya sebagai pemecah persoalan di masyarakat dengan langkahlangkah melakukan perubahan, evaluasi atau menilai dampak sosial atas pekerjaan tertentu (Blaikie 2000:72) Intinya, ilmu pengetahuan pragmatis tidak hanya "tahu bahwa", "tahu akan", dan "tahu mengapa", tetapi juga "tahu bagaimana?" .

Di dalam kampus begitu mudah kita enteng diskusi tentang isu-isu sosial tertentu, tetapi pada praktik lapang tidak semudah itu. Kerja lapangan membutuhkan cara-cara yang cepat menjawab langsung case-case yang bermunculan dan memberikan penyelesaian masalah sosial lapang. Sementara itu ilmu murni bingung pada saat menghadapi persoalan-persoalan praktis yang tidak teramalkan sebelumnya.

Penulis menyaksikan sendiri bahwa problem sosialisasi menjadi salah satu pemicu dari kemunculan Konflik Lingkungan di Kota Batu. Pertanyaan akan 
berhubungan dari proses sosialisasi dan kesediaan masyarakat menerima proses sosialisasi tersebut. Jika hanya berkutat pada ilmu teori kita akan menjelaskan tentang definis, bentuk, dan strategi sosialisasi kognitif, namun dalam praktik, persoalannya tidak sesederhana itu, pada kondisi masyakat yang sedang gelisah dilakukan sosialisasi yang berpotensi merusak sumber air, tentulah langkah yang sulit. Disinilah akan problematik, peran sosiolog akankah berhenti pada pengembangan konsep atau penyelesaian masalah secara tuntas?

c) Bekerja di tataran praktis

Sosiologi terlalu percaya diri dengan menyatakan bahwa hasil pekerjaan sosiolog bisa dimanfaatkan siapapun. Mendampingi masyarakat miskin merupakan pekerjaan lapang yang membantu mengangkat harkat martabat kaum papa. Membantu calon walikota memenangkan kompetisi juga pekerjaan lapang yang berkontribusi untuk memenangkan pada pilkada. Membantu pemerintah membuatkan proposal proyek juga kerja lapangan yang ada manfaatnya karena gagasan sosiolog akan diadopsi para pengambil kebijakan. Agar lepas dari dilema di atas, bekerja pada level praktis adalah keharusan karena ia membuka jalan bagi para sosiolog untuk berbuat dan mengembangkan konsep atau teori.

Dilema-dilema pengembangan Sosiologi berkaitan dengan ketiadaan fokus yang jelas. Di perkuliahan dan forum-forum akademik kita cenderung enteng untuk mendiskusikan tema-tema sosiologi. Ironisnya kita tidak memikirkan sampai di lapang bahwa persoalannya tidak sesederhana yang disampaikan itu. Misalnya, kita katakan relasi masyarakat dengan perusahaan harus harmonis, tetapi di lapangan tidak sesederhana itu menginbat banyak variabel yang tidak dijelaskan pada diskusi. Penulis menemukan kesadaran ini ketika menjadi tim peneliti kampus untuk mengevaluasi community development sebuah perusahaan di Bojonegoro, Jawa Timur pada tahun 2009.

Warga desa yang berada pada Ring Satu lokasi eksplorasi tambang minyak ternyata memiliki tingkat kekritisan lebih tinggi dari pada mereka yang tinggal di ring-ring yang lain. Kemudian, warga tersebut meminta solusi kepada peneliti agar mereka memperoleh keuntungan langsung dari praktik tambang tersebut. Penulis memikirkan secara hati-hati dengan menyatakan bahwa kondisi lapangan lebih kompleks dari pada materi di kelas. Refleksi penulis yaitu, manakah bukti dari buku-buku yang dibaca dengan menyatakan CSR (corporate social responsibility) telah melahirkan kolaborasi negara, masyarakat, dan korporasi?

Hal yang sama ketika mempelajari konsep gerakan sosial. Di kebanyakan buku-teks dijelaskan penyebab kemunculan, jenis-jenis, dan tipologi gerakan sosial, tetapi pada saat penulis mendampingi tokoh gerakan lingkungan menghadapi gugatan pidana dan perdata, konsep-konsep di buku tidak persis ditemukan di lapang. Justru ada banyak varian di sana yang melekat dalam budaya lokal. Dalam memberikan pernyataan terkait gerakan, penulis lebih berhati-hati karena ada konsekuensi waktu itu yaitu penjara dan hukuman pidana. Dari sinilah, sosiologi harus mengembangkan keterampilan lapang yang benar-benar terapan. Dalam mengembangkan sosiologi, profesionalisme itu perlu. Kritik pada pendekatan 
puritan elitis yakni praktik ilmu sosial yang berhenti pada pengajaran, penelitian dan pengabdian saja menyisakan persoalan-persoalan bagi pembelajar sosiologi. ${ }^{2}$

Kita perlu memikirkan kelebihan-kelebihan dari pendekatan pragmatis, sebagai berikut:

1. Mengakomodir pendekatan sosiologis

Pendekatan lapang bukan berarti mengesampingkan konsep dan teori, pendekatan ini masih memperhatikannya. Hanya saja ia diletakkan di awal sebagai penilaian persoalan (problem assessment) yang kemudian dilanjutkan pada bagian tindak lanjut untuk menyelesaikan persoalan tersebut. Konsep alienasi misalnya, sebagai alat analisa tentang kondisi pekerja yang selanjutnya merekomendasikan pemberdayaan untuk manusia.

2. Berorientasi perubahan

Sosiologi lapang berarti menjadikan data-data lapang sebagai data sekunder, apakah akan diperlakukan sebagai alat untuk memahami realitas sosial atau akan diubah mengikuti arah yang ditetapkan peneliti. Oleh karena itu peneliti harus benar-benar memahami esensi pengetahuan lapang itu. Misalnya, datadata lapangan adalah kontinu dan sering berserakan dan tidak pernah selesai.

3. Humanis

Keberpihakan peneliti sangat jelas. Bertemu dengan lapang berarti melibatkan semua komponen panca indera, baik melihat, mendengar, memegang merasakan apa yang terdapat di lapangan itu. Efek positif yakni kesadaran untuk selalu belajar dan menemukan banyak hal/ temuan-temuan menarik yang tidak dibahas pada buku-buku yang mereduksi. Tidak hanya berkutat kepada data-data taktis lapangan, tetapi dengan dialog antara insider dengan outsider juga harus melahirkan teori-teori dari lapangan tersebut. Pendekatan ini menarik karena orientasi perubahan.

4. Praksis

Praksis menunjuk karakter ilmu sosial yang berimplikasi pada aksi yang berpihak. Ilmuwan berteori tidak hanya menjelaskan fenomena tertentu tetapi juga mengubahnya sampai pada tataran perubahan sosial.

Sama dengan semua pendekatan dalam sosiologi, pendekatan pragmatis juga tidak steril dari kritik. Metodologi pragmatis yang memihak pada kepentingan tertentu sering dipersoalkan oleh akademisi-akademisi positivistik sebagai melanggar etika ilmuwan. Misalnya, karena penelitian pragmatis harus menetapkan tujuan, intervensi, produk jangka pendek dan keberpihakan, pendekatan ini sering dituduh "politis". Tidak heran, para pengembang jatuh mental karena bagi akademisi kampus, kata-kata politis ini menjadi momok yang membuat rendah diri dan kurang percaya diri.

2 Terkait dengan hal ini menarik sekali yang dinyatakan oleh Kepala BAPPEDA Kabupaten Malang yang menyambut baik orientasi pengajaran Sosiologi UMM yang sudah menggabungkan lapangan dan teori. Model seperti ini penting untuk mengintegrasikan "ilmu di kampus dengan kehidupan nyata, sehingga ketika mahasiswa lulus tidak berada dalam kegelapan" Kuliah Tamu Jurusan Sosiologi, 5 Juni 2015, Strategi Pembangunan Berbasis Komunitas di Kabupaten Malang. 
Dalam konteks tertentu status peneliti akan dinilai akademisi berwajah LSM. Bayangan mereka, akademisi itu makhluk pasif yang siap bekerja jika dimintai masukan oleh stakeholders. Peran akademisi tidak boleh kreatif, pokoknya melayani stakeholders saja. Sementara itu aktivis LSM lebih banyak bekerja di lapang dari pada menganalisa persoalan secara mendalam. Demikian pula, ketika bekerja di lapang LSM terlalu berpihak dari pada civitas akademika yang memperjuangkan “obyektivitas". Pembedaan keduanya banyak dinilai secara dikotomis.

Politis di sini bisa dipertanyakan, seperti yang selalu dipertanyakan oleh para penganut teori kritis, pertanyaannya, apakah yang non politis itu pasti obyektif dan tidak berpihak? Ketika ada ketimpangan sosial sementara ilmuwan sosial tidak bisa berbuat dan sebatas melakukan aksi 'diam' itu sama artinya berpihak yaitu berpihak pada 'status quo' pihak-pihak yang diuntungkan?

Kalaupun kita mengakui bahwa memang sebagai akademisi politis, lantas apakah politis itu haram atau tidak boleh? Apakah keberpihakan itu pasti dimaknai sebagai sesuatu yang negatif? Relakah Saudara ketika ada kelompok masyarakat yang rentan dan terancam kebijakan menindas, kita diam saja? Bukankah keberpihakan ini adalah perbuatan mulia, sebuah kesempatan sebagai khalifah Allah dimana peluang amal saleh ini akan sia-sia bila dilewatkan. Di sini penelitian ilmu sosial tidak lepas dari praktik ketuhanan dan kenabian yang membebaskan orang-orang papa dari penindasan struktur.

\section{Membangun "Rumah" Sosiologi}

Setelah memahami persoalan dan perdebatan dalam sosiologi kita memasuki langkah-langkah membangun Sosiologi sebagai rumah ilmu pengetahuan (science) yang benar-benar berkontribusi. Rumah menunjuk sebagai bangunan yang didalamnya terdapat berbagai kehidupan dan barang untuk pemenuhan hidup. Ia juga dilindungi oleh alat, lantai dan jendela yang membuat penghuni krasan di rumah. Karena krasan inilah maka lahir karya-karya besar.

Untuk menjawab ini penulis menggunakan implementasi, evaluasi dan refleksi selama berkiprah di Program Studi Sosiologi UMM, tempat penulis berkarya sehari-hari. Terus terang, penulis banyak menginisiasi kegiatan-kegiatan untuk pemahaman ini. Untuk itu, langkah-langkah yang bisa dilakukan penulis ringkaskan sebagai berikut.

\section{a) Pemahaman konsep-konsep dasar}

Belajar sosiologi diawali dari memahami dan mengusai konsep-konsep dasar sosiologi yang dilanjutkan dengan penguasaan konsep-konsep lanjutan. Pekerjaan ini bisa dilakukan melalui penguasaan materi yang diajarkan bangku kuliah ataupun membaca literatur secara mandiri. Untuk semakin memahami konsep-konsep dasar, maka para pembelajar harus menguasai konsep-konsep dasar sosiologi. Kita mudah menemukan dari buku-buku sosiologi dasar. Referensi seperti konsep dasar (key concept) harus dicari sebanyak-banyak. Ada yang mendasarkan pada isu yang ditekuni dalam sosiologi ada pula yang ditekuni para Sosiolog. Konsep-konsep yang dikembangkan dalam sosiologi 
politik memuat konsep-konsep dasar tertentu dan demikian pula konsep-konsep tertentu dikembangkan oleh Karl Marx, misalnya. Dalam sosiologi dikenal istilah perspektif teoritis (theoretical perspective), maka dengan mencari konsep-konsep dasar tersebut kita akan mudah mengaplikasikannya pada suatu analisis. Target dari pemahaman konsep yakni mampu berfikir sosiologis.

b) Pengembangan teori

Tradisi bersosiologi harus kreatif. Kita tidak boleh puas hanya menekuni atau berkutat pada konsep tertentu saja. Kita juga tidak boleh puas hanya pada level memahami definisi konsep atau teori, tetapi harus dikembangkan kaitankaitan dengan konsep-konsep atau teori-teori lain.

Misalnya, penulis melahirkan karya tentang Integrasi Ilmu Sosial (2005) yang merupakan upaya menggabungkan tradisi-tradisi filsafat baik yang muncul pada Peradaban Yunani, Islam, dan Barat. Penulis menggali kontribusi antar peradaban Yunani, Islam, dan Barat dalam kontribusi peradaban. Persoalannya, relasi antar peradaban itu terputus, padahal ada titik-titik integrasi yang bisa menghubungkan ketiga peradaban itu. School of thought ketiganya dielaborasi yang akhirnya menghasilkan modifikasi ilmu pengetahuan sosial baru yang lebih mutahir.

Penulis tidak puas dengan integrasi sosial, maka dikembangkan menjadi studi yang lebih spesifik. Pada saat menyelesaikan tesis master di UGM, penulis tertarik dengan kajian pengelolaan sumber daya alam melalui sistem co-management. Konsep ini menunjuk pengelolaan bersama antaraktor dalam mengelola sumber daya alam. Pengelolaan tersebut mengundang keterlibatan semua stakeholders pengelola sumber daya alam untuk berpartisipasi demi memperoleh tujuan-tujuan ganda. Prinsip utama agar sistem ini berhasil yakni meletakkan integrasi sebagai basis berfikir.

Persoalannya, co-management saja tidak cukup, maka penulis perlu memasukan pembelajaran sosial (social learning) pada praktik co-management. Setelah itu penulis mengembangkan gagasan tentang gerakan lingkungan dengan basis co-management.

Tidak berhenti di sini, co-management dikembangkan dengan konsep governansi/tata kelola (governance). Governance merupakan salah satu perspektif dalam menganalisa co-management. Kini penulis mengembangkan tata kelola yang menjadi tujuan dari pengelolaan sumber daya alam itu. Sekali lagi, basis utama yakni integrasi ilmu sosial. Pekerjaan ini tampaknya tidak akan pernah berakhir karena perkembangan-perkembangan lapang sangat bergerak cepat.

c) Memetakan persoalan-persoalan lapang

Salah satu cara membantu memahami konsep-konsep sosiologi tersebut dengan menghubungkan realitas lapang. Namun, tidak semua realitas lapang diperuntukkan pembelajar, sebab ketika di kos pun, mahasiswa sesungguhnya berada di area 'lapangan. Lantas apa beda antar keduanya? Di sini sesungguhnya dosen menjadi pengarah kegiatan mahasiswa untuk memilih realitas lapang dan konsep-konsep yang diberikan termasuk pada level awal, menengah sampai akhir. Tidak semua dosen yang menguasai mampu menjalankan hal ini karena 
ada proses transfer di lapangan.

Di Program Studi Sosiologi FISIP UMM, proses transfer tersebut dilakukan melalui kegiatan live in yang diselenggarakan sejak 2012, dan ternyata kegiatan ini berefek pada pemahaman kasus-kasus lapang. ${ }^{3}$ Sambil kerja sama, memetakan masalah lapang membantu mengembangkan sosiologi itu sendiri. Langkah yang realistis dan bisa dilakukan yakni mencari potensi- potensi khas desa/kelurahan yang bisa dimanfaatkan untuk pembelajaran sosiologi. Pemilihan tentunya fleksibel sangat bergantung pada konsentrasi atau kompetensi yang dipilih oleh program studi atau kelompok studi tertentu.

d) Pemahaman best practices

Masih terkait poin pertama, data-data lapang bisa membantu memahami konsep-konsep dasar, namun tidak semua; ada data lapang yang berhubungan dan tidak berhubungan dengan Sosiologi. Demikian pula ada data lapang berkualitas dan tidak berkualitas. Kualitas ditentukan dari tingkatan, manfaat dan fokus yang akan ditekuni.

Contoh data berkualitas yakni best practice atau contoh terbaik di lapang. Best practice tidak harus karya para sosiolog, sebab banyak aktivis lapang atau bahkan orang awam berhasil menciptakan best practice sesuai minat dan bidangnya. Memahami best practise itu memudahkan mahasiswa menangkap fenomena sosiologi, ketika di lapangan mereka mendengar, melihat, merasakan sendiri dan bahkan terlibat dengan fenomena sosial yang dijadikan sebagai sasaran belajar.

Dosen bisa meminta untuk melakukan penelitian lapang atau magang pada kelompok-kelompok masyarakat tertentu. Program pemberdayaan masyarakat, seperti: program penghijauan dan penyelamatan lingkungan menjadi sasaran pembelajaran mahasiswa. Mereka bisa belajar tentang pemberdayaan masyarakat oleh karena itu mahasiswa diwajibkan menginisiasi kegiatan-kegiatan dari awal sampai eksekusi program-program lapangan.

Dosen bukan tukang memberi penugasan, tetapi ikut terlibat seperti yang dilakukan mahasiswa. Dosen harus benar-benar mengerti yang dipikirkan mahasiswa dan apa kebutuhan mereka di lapang. Tentunya dosen berperan sebagai pendamping mahasiswa. Pekerjaan ini tidak cukup satu jam atau dua jam, satu hari atau dua hari, tetapi beberapa bulan. Langkah ini telah dipersiapkan di kampus dengan bekal-bekal konsep yang memadai, kemudian dilakukan monitoring pekerjaan mahasiswa. Akhirnya, dosen mengevaluasi sejauh mana mahasiswa menangkap rencana pembelajaran.

e) Pengembangan mata kuliah berbasis lapang

Pengembangan mata kuliah dibagi menjadi dua yakni mata kuliah berbasis teori dan mata kuliah lapang. Jika mata kuliah teoritis memberi bekal pemahaman pada konsep-konsep dan teori-teori tertentu, mata kuliah lapang selain memahamkan konsep, juga membekali metodologi dan ketrampilan-ketrampilan

3 Yakni selain mahasiswa memahami lapang juga mendekatkan diri dengan realitas tersebut. Hal ini live in disetting dengan kegiatan yang bertujuan menggabungkan antara berfikir dan berkreasi. 
lapang. Output keduanya jelas tidak sama; mata kuliah teori bertarget memahami dan menguasai, mata kuliah lapang mampu mempraktikkan di lapang.

Selama ini, banyak pembelajar yang "gagal” berteori. Salah satunya, kesulitan membayangkan konsep dan teori sosiologi. Bukankah membayangkan keduanya utamanya studi sosiologi makro membutuhkan abstraksi tingkat tinggi, maka pembelajaran berbasis lapang membantu memudahkan praktik konsep atau teori itu. Hal ini karena relasi pembelajar dengan kenyataan sosiologis begitu dekat. Bukankah, karya-karya besar seperti yang dihasilkan Geertz atau Heru Nugroho merupakan upaya mengenali lapang secara akademis?

\section{f) Melahirkan kerja kolaborasi yang berkelanjutan}

Penulis menyadari bahwa sosiolog itu bukan sekelompok elit penguasa kebenaran yang mampu menyelesaikan semua masalah sosial dan kemanusiaan. Kehadiran sosiolog bukan seperti malaikat atau Sinterklas pemberi hadiah. Memang, masih ada anggapan tentang kepakaran yang menggambarkan sosiolog sebagai penyelesai yang menjaga jarak.

Penulis nyatakan bahwa sosiolog tidak bisa menyelesaikan masalah tanpa kerja dengan masyarakat. Mau tidak mau, kolaborasi dengan semua stakeholders sehinggga mampu menginisiasi kerja-kerja lapang dan obyek bahasan sosiolog. Landasan etis dan profesional tentunya harus digunakan.

Pembelajar sosiologi harus jeli mengenali lokasi yang bisa dimanfaatkan untuk aktualisasi teori sosiologi. Misalnya, mengembangkan desa-desa mitra bisa membantu memantapkan konsep, teori dan model pengembangan sosiologi. Langkah yang dilakukan yakni mengenali orang-orang kunci di komunitas tersebut yang selanjutnya menjadi partner sosiolog. Kerja bersama dengan partner itu sesungguhnya membantu mengenali realitas lapang. Kemudian setelah itu, penggalian potensi-potensi wilayah dikembangkan dengan kerja kolaborasi bersama dengan pembelajar sosiologi yang lain. Ingat partner tetap diposisikan sebagai orang yang memiliki tujuan yang kebanyakan tidak akademis. Para pembelajar sosiologi harus menghormati hal tersebut.

\section{g) Merawat relasi komunitas mitra}

Kolaborasi harus dilakukan secara disiplin karena target yang dicapai mengonstruksi pengetahuan bersama. Pengetahuan itu baik yang dirumuskan dari tradisi kampus maupun yang dikonstruksi masyarakat melalui pengetahuan lokal mereka, maka kolaborasi harus selalu dirawat. Salah satu cara yakni menjaga relasi mitra dengan kerja sama akademik/non akademik. Pada saat mitra dirundung masalah, pembelajar sosiologi turut dalam menyelesaikannya. Ingat, pekerjaan kolaborasi bertujuan melahirkan konsep, teori maupun metodologi baru, Selain itu memberi inspirasi dan penyelesaikan masalah bagi mitra. Untuk itu, ia tidak boleh sehari atau dua hari saja. Relasi dengan mitra harus selamanya.

\section{Tantangan Merawat Sosiologi}

Setelah memahami model pembelajaran sosiologi baik berbasis teori maupun 
lapang kita memikirkan bagaimana menjaga konsistensi belajar Sosiologi itu, mengingat ia bukan kerja yang mudah.

a) Pekerjaan sosiolog ke depan

Untuk membersemai sosiologi, penulis menyatakan bahwa melahirkan sosiolog-sosiolog ideologis merupakan kebutuhan. Ideologis yang penulis maksud bukan menunjuk pada aliran tertentu atau berbentuk sosiolog tanpa kritik. Ia menunjuk etos jangka panjang untuk pengembangan sosiologi dan proyeksi masyarakat ideal.

Sosiolog ideologis tidak boleh setengah-setengah. Ia menjauhi repetisirepetisi atau pengulangan-pengulangan atas konsep-konsep/teori-teori yang sudah banyak dikaji. Misalnya, setiap penelitian selalu saja menggunakan teori tindakan sosial, terus rata-rata ilmuwan meneliti itu. Para ahli sedang ramai mengkaji modal sosial, maka ramai-ramai pula para sosiolog membincangkan itu. Kalau hal itu terjadi biasanya didorong motif pragmatis yang seharusnya dihindari para pembelajar sosiologi.

Manakah konsep-konsep sosiologi lain seperti identitas sosial? atau konsep panjat sosial atau proyeksi masyarakat ideal seperti yang selalu dinyatakan sosiolog klasik tidak pernah dipikirkan. Terkait ini penulis berkeyakinan bahwa untuk mengembangkan sosiologi dan menghasilkan karya-karya lapang dibutuhkan semangat dan mental baja.

Semangat ini nantinya akan berkontribusi atas lahirnya kultur akademik sebagai berikut:

1. Kegiatan pengajaran yang serius dengan maksud mewujudkan transfer pengetahuan, pencerdasan dan pencerahan.

2. Meneliti tanpa kenal lelah dengan maksud mencari kebenaran atau inovasi yang berkelanjutan.

3. Wacana kritis yang berkelanjutan sehingga terjadi debat tanpa henti-hentinya dalam komunikasi akademik tanpa memunculkan kebencian-kebencian.

4. Publikasi secara serius hasil penelitian

5. Menerapkan secara kritis hasil pemikiran dan penelitian untuk kemaslahatan masyarakat (Nugroho 2006: 181).

\section{b) Tantangan berteori di tengah sistem pragmatis}

Pekerjaan berteori merupakan pekerjaan utama sosiolog. Pengalaman membuktikan bahwa sosiolog besar seperti Emile Durkheim, Karl Marx, Max Weber, dan sosiolog-sosiolog lain dikenal karena teori-teori besar mereka. Namun demikian, kondisi masyarakat hari ini menyebabkan situasi lain. Sistem yang pragmatis meletakkan pandangan bahwa berteori bukan "gengsi sosial". Gengsi bukan diukur dari karya teoritis tetapi keberhasilan material, sekalipun dicapai dengan instan. Disinilah kerja keras menghasilkan teori tidak dianggap sebagai pekerjaan ampuh.

Kondisi ini melahirkan model-model pengembangan ilmu pengetahuan yang menjadikan ilmu sebagai tujuan atau sebagai instrumen untuk kepentingan- 
kepentingan lain? Memosisikan ilmu sebagai ilmu saja atau menggabungkan dengan moral, nilai-nilai dan etika. ${ }^{4}$ Dengan kalimat lain, cukup menjadikan materi yang sekedar diajarkan di kelas, atau tercermin dalam sehari-hari akademisi sebagai cara hidup (way of life).

Seorang dosen yang menekuni perilaku kolektif (collective behavior) misalnya, seharusnya rela mengorbankan banyak waktu untuk pengembangan keilmuan yang tidak hanya pada waktu formal saja. Ia selalu bergelut dengan realitas sosial lapang. Ia akan melayani semua pihak tanpa memandang status sosial pada saat diajak berdiskusi tentang gerakan sosial.

Sedangkan ahli yang menjadikan ilmu sebagai instrumen hanya berhenti dalam teori atau kajian-kajian di kelas atau di forum-forum ilmiah. ${ }^{5}$ Sekalipun banyak stakeholder yang ingin sekali berdiskusi dengannya, biasanya kesempatan tertutup karena ia ekslusif. Godaan-godaan pragmatis ini menyebabkan kita tidak bersemangat dalam mengkaji sosiologi, akhirnya lahirlah karya asal-asalan. Ketika etos rendah digabung pekerjaan secara asal-asalan maka hasilnya jauh dari kepentingan membangun keilmuwan sosiologi. Pada kondisi seperti ini sesungguhnya tidak ada kontribusi signifikan sosiologi pada masyarakat. Ilmu sekedar melayani kemauan negara dan pasar.

\section{Penutup}

Dari diskusi yang dilontarkan penulis saatnya kita menyadari bahwa kontribusi sosiologi masih minim dan perlu dipertanyakan. Hal ini terjadi karena masih ditemukam persoalan-persoalan pada pengembangan sosiologi sebagai sebuah ilmu dan sosiolog yang berperan mengembangkan ilmu pengetahuan tersebut.

Kenyataan lapang menggambarkan bahwa rata-rata statemen sosiolog di publik tidak matang. Tidak heran jika akurasi sosiolog dipertanyakan ilmuwanilmuwanlain. Kondisiini karena berlevelmemahamirealitas yang didukung dengan literatur atau bacaan sekenanya. Untuk itu, tujuan dan target pengembangan ilmu

4 Perdebatan ini mewarnai sejarah ilmu pengetahuan. Skolimowski menjelaskan tiga tahapan ilmu pengetahuan dan nilai-nilai. Tapahan pertama di Era Plato, pengetahuan dan nilainilai memiliki aspek yang sama dan bersifat digabung. Tahapan kedua di Era Immanuel Kant dimana penggabungan pengetahuan dan nilaim tetapi pengetahuan di bawah nilai-nilai gereja dan tahapan ketiga di Era Francis Bacon dimana pengetahuan di atas nilai-nilai. Lihat Skolimowski, 2004.

5 Penulis senang dengan kalimat, “...disinilah apakah ilmu sampai ke hati, atau hanya berjalan dari mulut sampai tenggorakan?" Inilah pertanyaan mendasar yang harus dijawab para sosiolog dalam memosisikan ilmu pengetahuan yang telah dipelajari selama bertahun-tahun. Hemat penulis, kegagalan sebagai Sosiolog kebanyakan bukan karena gagal memahami konsep-konsep sosiologi, tetapi gagal mempertahankan tradisi berteori di tengah godaan-godaan pragmatis di masyarakat. Ilmuwan sosial "lelah" karena tidak ada kompensasi "menjanjikan" dalam berteori. 
sosial itu harus ditetapkan. Dengan memahami tujuan, akhirnya belajar sosiologi juga tidak asal-asalan.

Namun pekerjaan itu tidak mudah, adakalanya pemikiran sosiolog tidak berguna mengingat sosiologi bukan profesi resmi di masyarakat, seperti: dokter, polisi, pengacara, hakim atau perawat. Hal inilah yang membuat posisi sosiolog cukup "sulit" untuk melakukan pengembangan terus menerus.

Berangkat dari hal ini, sosiolog perlu melakukan refleksi terus menerus dengan memikirkan sampai "untuk apa" ilmu ini diciptakan dan apa efek atau dampak dari pekerjaan ilmuwan sosiologi tersebut kepada masyarakat. Ilmuwan tidak berhenti memahami realitas, tetapi juga membuktikan temuan-temuan tersebut. Misalnya, sosiolog memiliki konsepsi tentang kebenaran teoritis dan lapang, maka ia membuktikan hal tersebut dengan menginisiasi perubahanperubahan seperti yang diidealkan.

Langkah-langkah penting yakni menilai persoalan mendasar sosiologi, diteruskan dengan bekerja pada prinsip dasar, mempertimbangkan studi lapang yang akhirnya ditutup membangun rumah Sosiologi. Kerja-kerja ini didasari pengetahuan, pengalaman dan target jelas dan terukur. Setelah itu pengembangan, evaluasi dan refleksi terus menerus dilakukan agar ilmu ini semakin berkembang untuk masa depan. 


\section{Daftar Pustaka}

Ali, Maulana Muhammad. 2020: Muhammad Sang Revolusioner. Jakarta: Turos Pustaka

Blaikie, Norman. 2000. Designing Social Research: the Logic of Anticipation. Malden, MA : Polity Press

Dharmawan, Awam Setia, Mochamad Aan Sugiharto. 2020. Belajar Sosiologi di Desa: Pengalaman Live in di Desa Sentra Bunga Mawar di Jawa Timur. Yogyakarta: LeutikaPrio.

Fernandes, Rajesh Tandon. 1993. Riset Aksi Riset Pembebasan. Jakarta: Gramedia Pustaka.

Bruhn, John G, Howard M. Rebach. 2007. Sociological Practice: Intervention and Social Change. New York: Springer Science and Business Media, LLC.

Heryanto, Ariel. 2006. Kiblat dan Beban Ideologis Ilmu Sosial Indonesia. Dalam Hadiz, Vedi R dan Danieal Dhakidae. Ilmu Sosial dan Kekuasaan di Indonesia. Jakarta: PT Equinox Publishing Indonesia

Keraf, Sonny A., Mikhael Dua. 2001. Filsafat Ilmu Pengetahuan. Yogyakarta: Kanisius

Nugroho, Heru. 2006. Ekonomi Politik Pendidikan Tinggi: Universitas sebagai Arena Perebutan Kekuasaan. Dalam Hadiz, Vedi R dan Danieal Dhakidae, Ilmu Sosial dan Kekuasaan di Indonesia. Jakarta: PT Equinox Publishing Indonesia.

Ritzer, George. 2013. Ekplorasi dalam Teori Sosial: Dari Metateori sampai Rasionalisasi. Yogyakarta: Pustaka Pelajar

Shihab, Quraish. 2020. Khilafah: Peran Manusia di Bumi. Tangerang: PT Lentera Hati

Skolimowski, Henryk. 2004. Filsafat Lingkungan: Merancang Taktik Baru untuk Menjalani Kehidupan. Bentang: Yogyakarta

Susilo, Rachmad K. Dwi. 2005. Integrasi Ilmu Sosial: Memadukan Ilmu Sosial Tiga Peradaban. Yogyakarta: Ar Ruzz Media

Susilo, Rachmad K. Dwi. 2007. Memahami Kecerdasan Orang-Orang Sukses: Refleksi Kisah Orang-Orang Ternama dalam Mensiasati Hidup. Jakarta: Studia Press.

Susilo, Rachmad K. Dwi. 2011. Co-management Air Minum untuk Kesejahteraan Masyarakat: Kasus di Desa sebuah Desa di Jawa Timur. Yogyakarta: Penerbit Samudra Biru.

Susilo, Rachmad K. Dwi. 2018. A Sociological Study on the Grassroots 
132 | Sosiologi Sebagai the Queen of Social Sciences: Sebuah Refleksi

Environmental Movement after Reformation in Indonesia : A Case Study of Water Sources Conservation Movement in Batu, East Java [Disertasi]. Tokyo: Hosei University Repository

Nugroho, Heru. 2012. Negara, Universitas dan Banalitas Intelektual: Sebuah Refleksi dari Dalam. Pidato Pengukuhan Jabatan Guru Besar pada Fakultas Ilmu Sosial dan Ilmu Politik, Universitas Gadjah Mada. 14 Februari 2012 di Yogyakarta

Soemardjan, Selo. 1994. Ilmu-Ilmu Sosial di Indonesia Mandek? Wawancara dalam Prisma No.1, Januari. 


\section{Pedoman Penulisan}

Naskah artikel ditulis dalam bahasa Indonesia atau bahasa Inggris dengan panjang 5000-8000 kata. Lebih dari 8000 kata ditoleransi dengan catatan bahwa kelebihan tersebut sepadan dengan data, informasi, serta analisis dan diskusi yang dikerjakan. Naskah merupakan hasil penelitian maupun refleksi kritis atas sebuah pemikiran, teori, atau metodologi dalam sosiologi atau ilmu sosial secara umum. Penting diingat bahwa naskah yang diajukan tidak tengah dalam proses pengajuan atau dalam proses telaah (review) di jurnal lain. Pengajuan naskah artikel dilakukan melalui menu submission (pengajuan) di website http://journal.unusia.ac.id/index.php/Muqoddima.

Naskah ditulis dengan menggunakan font Book Antiqua pada program Microsoft Word, dengan ekstensi .doc, .docx, atau .rtf. Sistem penulisan secara umum adalah sebagai berikut:

\section{Judul}

Judul merefleksikan isi tulisan, singat, padaat dan diupayakan menarik minat pembaca. Font sebesar 20 poin, dengan huruf kapital di depan setiap kata (Capitalized Each Word) kecuali kata sambung. Panjang judul tidak lebih dari 10 kata. Hindari menggunakan tanda kurung (...) dalam judul.

\section{Nama dan identitas penulis}

Nama lengkap penulis dicantumkan tanpa gelar akademik, disertai keterangan institusi dan alamat email.

\section{Abstrak dan kata kunci}

Abstrak ditulis dalam bahasa Indonesia dan bahasa Inggris dengan panjang antara 150-250 kata. Abstrak seutuhnya ditulis dalam bentuk naratif memuat kajian, tujuan penelitian, metodologi, temuan, dan argumentasi. Kata kunci maksimal terdiri atas 6 (enam) kata/frasa.

\section{Tubuh artikel}

Tubuh artikel ditulis dengan ukuran huruf 11 poin, kecuali untuk sub judul (13 poin) dan catatan kaki (10 poin). Setiap awal paragraf ditulis menjorok ke dalam sepanjang 1 $\mathrm{cm}$. Penggunaan kata-kata asing dituliskan secara miring (italic). Tubuh artikel memuat empat komponen pokok meliputi (1) pendahuluan, (2) metode/cara kerja, (3) analisis dan diskusi, dan (4) kesimpulan.

\section{Catatan kaki}

Catatan kaki dituliskan hanya jika diperlukan, yakni untuk memberikan keterangan tambahan atasu suatu hal spesifik yang tidak sinambung secara langsung bila diletakkan sebagai bagian tubuh artikel. Hindari menggunakan catatan kaki jika berkenaan dengan sumber rujukan teoritis atau sumber data primer.

\section{Daftar Pustaka}

Daftar Pustaka ditulis dengan mengikuti standar format ASA (American Sociological Association). Format ASA juga berlaku dalam penulisan kutipan di tubuh artikel, termasuk 
catatan perut dan catatan kaki (note, footnote).

Berikut ini adalah berapa contoh penulisan isi Daftar Pustaka:

Andreassen A., Bard. 2007. "Human Rights and Legal Empowerment of the Poor", Extreme Poverty and Human Rights Expert Seminar, Geneva 23-24 February 2007, Norwegian Centre for Human rights, University of Oslo.

Fatoni, Muhammad Sulton. 2015. Kapital Sosial Pesantren (Studi Tentang Komunitas Pesantren Sidogiri Pasuruan Jawa Timur). Jakarta: Universitas Indonesia.

Geertz, Clifford. 1965. "Religion: Anthropological Study", dalam David L. Sills (ed.) International Encyclopedia of the Social Sciences. London: Collier-Macmillan Publishers.

Jones, Bobby L., Daniel S. Nagin, dan Kathryn Roeder. 2001. “A SAS Procedure Based on Mixture Models for Estimating Developmental Trajectories." Sociological Methods and Research 29 (3):374-93. Diakses pada 26 April 2005 (https://journals.sagepub. com/doi/10.1177/0049124101029003005).

Kukathas, Chandran. 2002. "Multiculturalism as Fairness: Will Kymlicka's Multicultural Citizenship." Journal of Political Philosophy 5(4):406-427. Diakses pada 27 Mei 2019. (https://onlinelibrary.wiley.com/doi/10.1111/1467-9760.00041)

Keterangan lebih rinci terkait ketentuan penulisan dapat diperiksa dalam Template Artikel MJPRS. 


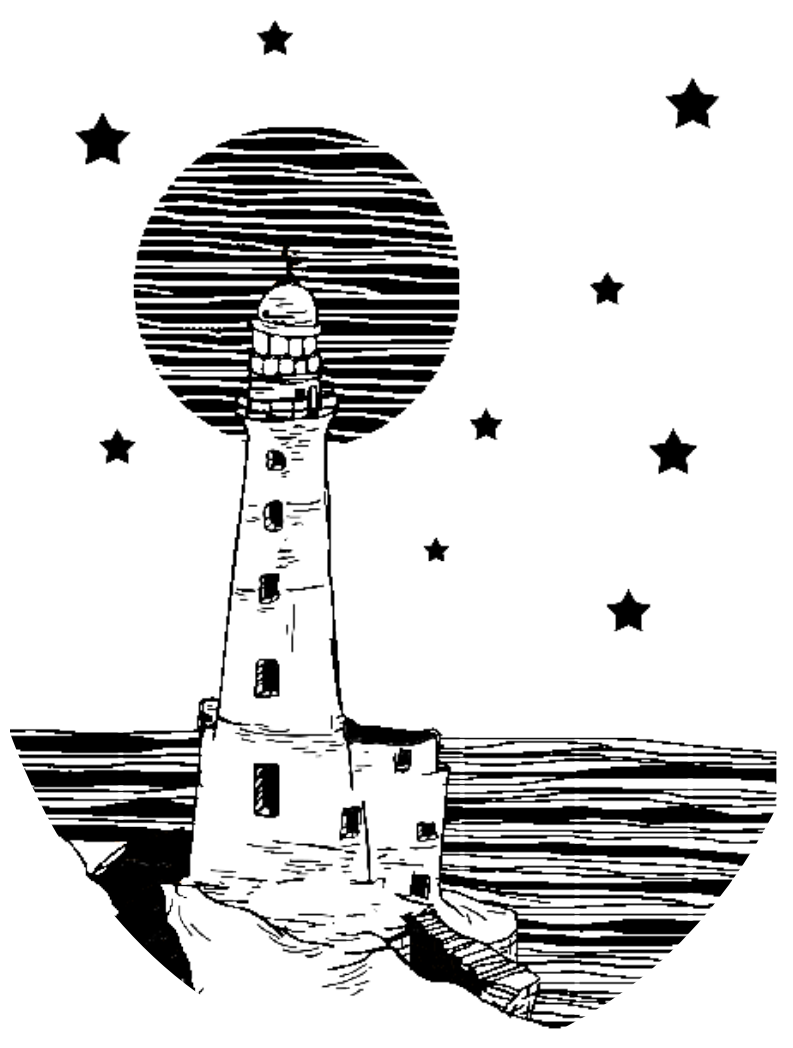



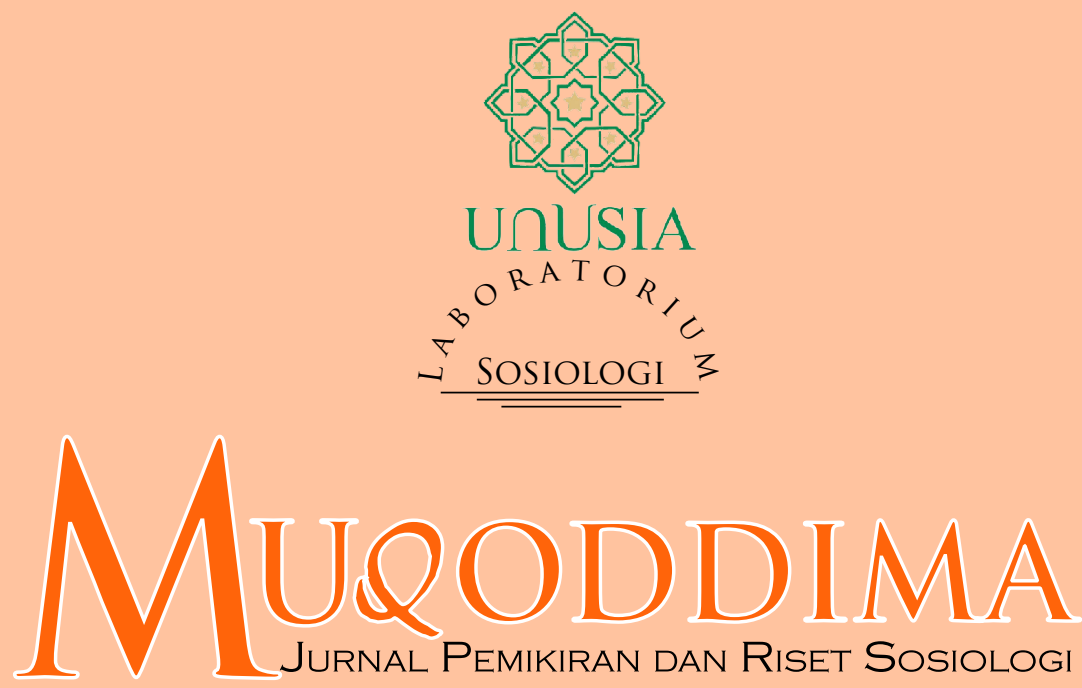